\title{
INTERNET

\section{The Content Analysis of the Internet Pages of the University's Faculty of Economics and Administrative Sciences}

\section{Üniversitelerin iktisadi ve idari bilimler fakültesi İnternet sayfalarının içerik analizi}

\author{
İrfan ERTUĞRUL ${ }^{1}$, iertugrul@pau.edu.tr \\ Abdullah ÖzçIL 2 , aozcil@pau.edu.tr
}

\begin{abstract}
This study investigated how effectively the Internet pages of business departments of universities in Turkey are used. Within the scope of the study, the business department's web pages of the universities operating in Turkey were analyzed by Content Analysis Method and Cluster Analysis Method. The sample analyzed in the study is composed of 21 universities selected according to the cluster sampling method. The ranking of universities that effectively use Internet pages is listed in the application section. The results of Cluster Analysis of the universities were evaluated using the Content Analysis scores of universities, base scores and the number of settled candidate numbers. According to the results of Hierarchical Cluster Analysis, it is determined that there is no differentiation between the universities according to regional, foundation year and university structure (state/private).
\end{abstract}

Keywords: University, Internet pages, Content Analysis, Cluster Analysis

Jel Codes: I29, L86, M19, C38.
Türkiye'de eğitim vermekte olan üniversitelerin işletme bölümlerinin Internet sayfalarm ne kadar etkin kullandıkları bu çalışma ile araştırılmıştır. Çalışma kapsaminda Türkiye'de eğitim vermekte olan üniversitelerin işletme bölümü İnternet sayfalar İçerik Analizi yöntemi ve Kümeleme Analizi yöntemi ile analiz edilmiştir. Çalışmada analiz edilen örneklem büyüklüğünü kümeleme yöntemine göre seçilen 21 üniversite oluşturmaktadır. Internet sayfaların etkin olarak kullanan üniversitelerin siralamasina uygulama bölümünde yer verilmiştir. Üniversitelerin İçerik Analizi puanları, taban puanları ve yerleşen aday sayıları değişkenleri kullanılarak üniversitelerin Kümeleme Analizi sonuçlar değerlendirilmiştir. Hiyerarşik Kümeleme Analizi sonuçlarına göre bölgesel, kuruluş yıll ve üniversite yapısına (devlet/özel) göre üniversiteler arasında herhangi bir farklllaşma olmadığı tespit edilmiştir.

Anahtar Kelimeler: Üniversite, İnternet sayfası, İçerik Analizi, Kümeleme Analizi

Jel Kodlarn: 129, L86, M19, C38.

\footnotetext{
${ }^{1}$ Prof. Dr., Pamukkale University, Faculty of Economics and Administrative Sciences

${ }^{2}$ Res. Asst., Pamukkale University, Faculty of Economics and Administrative Sciences
} 


\section{INTRODUCTION}

As technological developments continue to increase rapidly, technology products have become an integral part of life. People use technology products in all kinds of living spaces at home, at work, on vacation, etc. and they can evaluate their time as they want. One of the most indispensable elements of these technological products is the Internet. The Internet has now become an indispensable part of people's lives.

Almost everything in the physical environment has been moved to the Internet in the last decade. In many countries all over the world, a large number of businesses and consumers spend a lot of time on Internet for a variety of purposes such as meet, chat, shopping, listening to music, watching or buying movies, getting information and so on (Çiçek et al., 2010: 188). Internet usage rate in Turkey is $80,7 \%$ of the households and $95,9 \%$ of the companies according to the Turkey Statistical Institute data of 2017 and the study conducted by Şahin and Gülnar (2016) shows that the average daily Internet usage time among students is 118 minutes. These and similar information shows the Internet penetration and usage.

Nowadays, the internet usage rate is quite high in education areas. The aim of this study is to compare the internet pages of the business department with qualitative and quantitative methods. Internet pages were compared with Content Analysis method. It has been tested by the Cluster Analysis method to determine whether there is any difference between universities in terms of year of foundation, regional or university structure (state/private). For this purpose, Content Analysis method and Cluster Analysis methods and literature researches have been mentioned first. In the application section, the analysis and its results are mentioned.

\section{CONTENT ANALYSIS}

Qualitative Content Analysis is the preferred analysis strategy for qualitative descriptive studies. Qualitative Content Analysis is a dynamic form of verbal and visual data in order to summarize the information content of the data (Sandelowski, 2000: 338). The researcher who makes qualitative analysis tries to discover and reveal the information hidden in data by acting on verbal and visual data. Therefore, it can be said that the qualitative data analysis has a different analysis method than the quantitative data analysis methods due to the testing of the hypothesis derived from the theories (Özdemir, 2010: 328).

Researches using Qualitative Content Analysis focuses on the content of the text or its contextual meaning and language features used in communication. Text data may be in verbal, printed or electronic format. It may have been obtained from narrative responses, open-ended questionnaires, interviews, focus groups, observations or printed media such as articles, books or hand brochures. Qualitative Content Analysis aims to classify large quantities of text in efficient categories that represent similar meanings. It calculates words intensively (Hsieh and Shannon, 2005: 1278).

The text analysis of all people requires an analysis of the contents in a general sense. Accordingly, continuous comparison, phenomenological and statistical analysis are examples of Content Analysis. However, in the research literature, 'Content Analysis' is a technical term that identifies specific approaches such as Quantitative and Qualitative Content Analysis (Sandelowski, 2000: 338). 
Content Analysis is a research technique for objective, systematic and quantitative identification of open communication content (Berelson, 1952: 18). Although the Content Analysis is relatively new to consumer research as an official methodology, it is not new to political science, journalism, social psychology, communication research, or political propaganda analysis (Kassarjian, 1977: 8-9).

Holsti (1969) presents a useful three-part typology, although the research questions that can be covered by Content Analysis are almost unlimited. First, researchers can focus on evaluating the message content and meaning by comparing the propaganda content of messages or the interfaces of messages. Second, researchers can examine the premises of messages. For example, psychologists can analyze texts and speeches to assess mental state. Finally, researchers can examine the message effects of multi-faceted research on the behavioral consequences of viewing television violence (Weare and Lin, 2000: 273).

Marying (2000) has developed Qualitative Content Analysis procedures that centralize the two approaches, induction category development, and deductive category implementation. Induction category development requires content to be available within the framework of qualitative approaches. The development of the viewpoint of interpreting the categories by formulating the contents is the basic view. In deductive category application analysis is taken by previously formulated and theoretically derived aspects. It works by linking them to text (Mayring, 2000: 4-7). According to Krippendorff (1980), six questions should be addressed in each Content Analysis:

- Which data is analyzed?

- How are the data defined?

- How many are the population?

- What is the content/context in which the data are analyzed?

- What are the limits of analysis?

- What is the goal of the inferences (Stemler, 2001: 2)?

Rather than being a single method, existing Content Analysis practices show three different approaches: traditional, directional, or summative. All three approaches are used to interpret the content of the text data and thus to conform to the natural paradigm. The major differences between approaches are coding schemes, the root of codes and threats to reliability. In the Traditional Content Analysis method, coding categories are derived directly from textual data. With a directed approach, analysis begins with a theory or related research findings as a guide for initial codes. A summative Content Analysis involves counting and comparing keywords or content and interpretation of the content. The authors describe techniques that address reliability with hypothetical examples and specific analytical procedures for each approach (Hsieh and Shannon, 2005: 1277).

In the literature, authors generally describe qualitative analysis techniques with seven qualitative techniques such as Continuous Comparison methods, Key Words in Content Context, Word Count, Classical Content Analysis, Field Analysis, Taxonomic Analysis and Component Analysis (Leech and Onwuegbuzie, 2007: 557). In the next part of the study, Content Analysis studies were included as a literature review. 
Mayring (2000) examined the application categories, processes, computer programs and application examples of induction and deduction approaches in Content Analysis research. Sandelowski (2000) tried to clarify the point to be considered in the method of Qualitative Content Analysis and application process by making a comparison from quantitative and qualitative researches. Weare and Lin (2000) suggested methodological improvement recommendations for Content Analysis application steps. Hsieh and Shannon (2005) distinguished the Content Analysis method three separate classes and demonstrated their differences as traditional, directed, and summarizing. Erdem (2005) identified the roles of Pamukkale University mission and vision in terms of current and future internal and external stakeholders by Content Analysis method and proposed the mission. Kurulgan and Bayram (2006) compared internet pages of libraries of state and private universities with Content Analysis method in terms of their activities. Bayram and Yayli (2009) classified the Internet pages of 51 hotels operating in Turkey in terms of 51 comparison criteria as yes/no. They analyzed the most and least features with Content Analysis. Becan (2011) examined the press releases the five largest banks operating in Turkey in terms of the importance for stakeholders with the Content Analysis method. Çiltaş et al. (2012) were analyzed by Content Analysis method the research trends of the articles between 1987 and 2009 for the field of mathematics education. Demirtaş and Özgüven (2012) analyzed the content of the internet pages of the mayor with 20 evaluation criteria. Güress et al. (2013) analyzed the Internet pages of airline operators and Content Analysis method to investigate the efficiency of marketing activities. The internet pages were rated according to the yes/no results of the questionnaire with 45 questions. The maximum total score is divided into 3 groups and the effective usage level of the Internet pages is determined. Çiçek et al. (2010) classified Internet pages of companies operating in Burdur in terms of their contents. The internet pages of the enterprises are separated into 3 groups. Each group has 21 properties and are named as "Effective, Medium Effect and Ineffective Usage". Ay and Koca (2012) analyzed the mission, vision, explanations, and concepts of Turkey's top 500 industrial enterprises with Content Analysis method. They have included the frequency values of the concepts prioritized by the industrial organizations. Yildiz (2014) analyzed by Content Analysis method the ad texts of higher education institutions in order to reveal the descriptive statistics of university perception. Erdem and Gezen (2014) analyzed the job advertisements of the companies operating in the tourism sector in order to classify them in terms of various criteria by means of Content Analysis. Tosunoğlu and Çam (2016) described issues and general characteristics of the graduate thesis written in costs in Turkey with the help of Content Analysis.

\section{CLUSTER ANALYSIS}

Cluster means to find groups of data. Aristotle's classification of living things is the first known hierarchical cluster. Along with the increase in knowledge of biology, the schematic organization of all known species is also a form of hierarchical cluster. Doctors describe their categorization by tumor characteristics. Astronomers group galaxies according to their shapes. Companies observe the users of the product group according to their behavior. Programs label an image's pixels with the object they belong to. Programs divide a video stream into segments according to the scenes. These systems perform Cluster Analysis while separating products into categories (Hennig et al., 2016: 2). 
A classification scheme can represent a suitable method for organizing a large data set so that it can be more easily understood and information can be retrieved more efficiently. If the data can be summarized in a valid way by a small number of object groups, the group tags can very clearly describe the similarity and difference models in the data (Everitt et al., 2011: 3). An algorithm can combine observations into groups to prevent false meanings and ignorance. It can also apply a more consistent grouping policy than a human to a major problem at the same time (Anderberg, 1973: 4).

Cluster Analysis is one of the statistical methods used extensively for data mining in various fields such as bioinformatics, genetics, archaeology, industrial engineering, astronomy, psychiatry, marketing, e-commerce and weather classification (Everitt et al., 2011: 9-13). Cluster Analysis techniques, which are used as a typical discovery analysis tool, include cases involving data and the degree of association between the two cases according to the target variables. Association degree of target variables is grouped to the maximum if they belong to the same group and to the minimum if they belong to a different group (Antonenko, 2012: 384).

For example Bonner (1964) suggested that the ultimate criterion for evaluating the meaning of cluster terms is the value judgment of the analyzer. The only thing needed to use a term such as a cluster is to produce a value to the researcher. At this point, Bonner's argument is not entirely convincing and many writers, such as Cormack (1971) and Gordon (1999), are trying to define what clusters are in terms of internal homogeneity and external isolation (Everitt et al., 2011: 7). In Cluster Analysis there are two nonverbal assumptions on the basis of the problem; (1) the selected characteristics are related to the desired set solution and (2) the validity of the measurement units (Duran and Odell, 1974: 31).

Cluster Analysis techniques relate to searching for objects that differ from a relatively small number of groups or similar clusters in terms of similarities, and to some sets of data that differ from units in other cluster. (Everitt et al., 2011: 13). Most cluster workspaces are divided into six main areas to help readers organize a wide variety of applications; (1) Life Sciences, (2) Health Sciences, (3) Behavioral and Social Sciences, (4) Earth Sciences, (5) Some Engineering Sciences, (6) Information, Policy and Decision Sciences (Anderberg, 1973: 5-6).

If each cluster is divided into subclusters, there is a hierarchical cluster. More generally, each subset can be further subdivided by adding new levels to the hierarchy or the clusters themselves can be grouped into "top clusters". The different approaches of the cluster analysis differ according to how the different clusters are related to each other and the data set. These different approaches are; overlapping clustering, hierarchies, fuzzy clustering, probabilistic clustering, coarse clustering (Hennig et al., 2016: 3-6).

For most applications of the Cluster Analysis, the basic data is the usual $n{ }^{*} \mathrm{p}$ multivariate data matrix with variable values that describe each object to be clustered and is shown in Equation 1.

$X=\left(\begin{array}{ccc}x_{11} & \cdots & x_{1 p} \\ \vdots & \vdots & \vdots \\ x_{n 1} & \cdots & x_{n p}\end{array}\right)$ 
The input in $\mathrm{X}$ gives the value of the variable $\mathrm{j}$ in object $\mathrm{i}$. Such a matrix is often referred to as two-mode, indicating that rows and columns correspond to different things. Indirect proximity are usually derived from $n^{*} p$ multivariate matrix $X$ (Everitt et al., 2011: 5-43).

An important effort to improve the clustering and classification methods has been to create methods based on minimizing the sum of error squares. These methods are called minimumvariance constraint methods and can be described and expressed in terms of square Euclidean distance (Duran and Odell, 1974: 19). For the similarity and distance measurement, the mathematical form of Euclidean distance is shown in Equation 2 (Everitt et al., 2011: 50).

$d_{i j}=\left[\sum_{k=1}^{p} w_{k}^{2}\left(x_{i k}-w_{j k}\right)^{2}\right]^{1 / 2}$

City Block Distance, Minkowski, Karl Pearson and Mahalanobis distance methods are also used in the measurement of distance values (Çakmak, 1999: 190-191). Similarity and distance values in the general form are summarized for six different cluster operations (Duran and Odell, 1974: 29), such as Nearest Neighbor, Most Neighbor, Median, Group Average, Centroid, and Ward method. Cluster Analysis algorithm;

- $\mathrm{n}$ objects are divided into g groups,

- $\quad$ The change in clustering criterion obtained by moving a group other than the group with each object is calculated,

- The value of the clustering criterion is modified to cause the greatest progress,

- $\quad$ The previous two steps are repeated until the movement of a single object improves the cluster criterion (Everitt et al., 2011: 121-122).

In the next part of the study, Cluster Analysis studies were included as a literature review. Ho and Hung (2008) aimed to develop effective marketing strategies for 5 different groups using Analytical Hierarchy Process, Cluster Analysis and Harmony Analysis methods together with the factors and impressions that were effective in university choice of students. Antalyalı (2008) achieved university-level organizational effectiveness levels of faculty members by questionnaire data with Factor, Cluster, Nonparametric Tests and Analysis of Variance methods. In order to use strategic orientations and resources effectively, the university activities levels were clustered in 3 groups as student orientation, internal orientation and expertise and environment orientation. Öz et al. (2009) evaluated Turkey and the European Union countries with different cluster numbers using 23 indicators related to education, health and labor market and Cluster Analysis. Doğan and Başokçu (2010) compared the results of different methods by grouping the students' attitudes towards the statistics lesson with the results of Factor Analysis and Hierarchical Cluster Analysis. Hosseini et al. (2010) determined the k-optimal values by the Davies-Bouldin Index in the kMeans method. Customer loyalty has been separated into clusters by a new model proposal in terms of marketing strategies. Lu et al. (2011) assessed the performance of air quality monitoring networks. Cities with similar air pollution and local emission sources were separated and analyzed by using 5 components by using Basic Component Analysis and Cluster Analysis. Antonenko et al. (2012) conducted an empirical study on on-line problemsolving strategies related to education technology. The students were divided into three groups as writing task, visiting related resources and visiting unrelated sources according to 
their activity periods with the help of Cluster Analysis. Kerr and Chung (2012) identified key characteristics of student performances in educational video games and simulations with the help of Cluster Analysis. Primack et al. (2012) analyzed the factors affecting drug addiction of university students. Student behaviors were divided into 6 groups with the help of Cluster Analysis to increase the effectiveness of drug addiction prevention programs. Üsdiken et al. (2013) analyzed the effects of diversity and concentration on the organizational structure of the universities. The results of the Cluster Analysis were compared in three different periods of ten years using 8 different variables. Vecchio and Annunziata (2013) examined the sustainable food purchasing behavior of university students by using Factor Analysis and Cluster Analysis. Student behaviors were categorized into three groups: responsible food consumers, careless food consumers, and potentially responsible food consumers for the purpose of market development. Aşan (2015) classified bank customers with socio-economic and demographic characteristics with the help of Cluster Analysis in order to better serve credit card users. Galloway and Bretz (2015) used the results of The Meaningful Learning in the Laboratory Instrument about expectations and experiences about the cognitive and emotional learning of the students of chemistry laboratory course in the Cluster Analysis. Kalimullin and Dobrotvorskaya (2016) distinguished socio-psychological factors affecting behaviors related to education and marketing strategy by using Cluster Analysis, Factor Analysis and Correlation Analysis. Erdoğmuş and Esen (2016) categorized into different clusters and different sizes as institutional dimension and performance in order to determine effective strategies for developing institutions by using 6 statistics variable data related to ranking, index, publication and annual reports and Cluster Analysis. Durrant (2017) classified students as 4 discipline groups in science/technology, humanities/social sciences, science and trade using the number of words in university students' writing and the Cluster Analysis. Postareff et al. (2017) obtained the emotions and success factors of university students in the first years by interviewing and questionnaire methods. The data are divided into groups by the Cluster Analysis. The students were divided into 3 groups in order to focus on successful learning as successful students progressing rapidly by experiencing positive feelings, successful students progressing rapidly by experiencing negative feelings and successful students slowly progressing by experiencing negative feelings.

\section{APPLICATION}

The scope of the study is based on departments of business administration. Candidates university students completed their high school education in Turkey may prefer this department. According to the information in the preference guide published by Center for Evaluation, Selection, and Placement (ÖSYM), there are 419 business departments that students can choose. International universities, foreign language education departments, open universities, second education departments and departments with empty quotas in 2017 were not included in the scope of the study. Therefore, the number of Turkish, formal, and primary education business departments belonging to different faculties constitute the main mass of the study as 131 .

Cluster sampling method was chosen as sampling method. For this reason, the main mass is clustered by 7 basic geographical regions and the sample size is determined as 21, with 3 universities having the highest base score in each region (Aktay and Ekşi, 2009: 23-24). 
Cluster Analysis criteria were quota, internet page Content Analysis scores, and base score. Table 1 gives the data for sequential sampling.

Table 1. The Comparison Data of Universities

\begin{tabular}{|c|c|c|c|c|c|c|c|}
\hline No & Region & $\begin{array}{c}\text { Foundation } \\
\text { Year* }\end{array}$ & $\begin{array}{l}\text { University } \\
\text { Structure }\end{array}$ & University & Base Point** & $\begin{array}{c}\text { Number of } \\
\text { Preferred } \\
\text { Candidates }^{* *}\end{array}$ & $\begin{array}{c}\text { Content } \\
\text { Analysis } \\
\text { Score }^{*}\end{array}$ \\
\hline 1 & Marmara & 1992 & State & Galatasaray & 460,41589 & 25 & 15 \\
\hline 2 & Central Anatolia & 2004 & Private & TOBB Ekonomi ve Teknoloji & 457,74456 & 60 & 53 \\
\hline 3 & Central Anatolia & 1966 & State & Ankara & 351,71895 & 61 & 18 \\
\hline 4 & Marmara & 1996 & State & Yıldız Teknik & 346,71328 & 90 & 31 \\
\hline 5 & Marmara & 2001 & Private & İstanbul Ticaret & 338,72629 & 92 & 66 \\
\hline 6 & Central Anatolia & 1995 & Private & Başkent & 330,20776 & 128 & 26 \\
\hline 7 & Aegean & 1992 & State & Ege & 320,51171 & 95 & 30 \\
\hline 8 & Aegean & 1944 & State & Dokuz Eylül & 290,83111 & 582 & 46 \\
\hline 9 & Southeastern Anatolia & 2008 & Private & Hasan Kalyoncu & 278,15365 & 21 & 41 \\
\hline 10 & Aegean & 2013 & State & İzmir Katip Çelebi & 271,73468 & 51 & 37 \\
\hline 11 & Mediterranean & 1996 & State & Akdeniz & 267,13423 & 205 & 27 \\
\hline 12 & Mediterranean & 1978 & State & Çukurova & 265,63481 & 278 & 40 \\
\hline 13 & Black Sea & 2009 & State & Ondokuz Mayıs & 256,06707 & 72 & 7 \\
\hline 14 & Mediterranean & 1992 & State & Mersin & 245,32763 & 82 & 38 \\
\hline 15 & Southeastern Anatolia & 1998 & State & Gaziantep & 244,42124 & 176 & 86 \\
\hline 16 & Black Sea & 2011 & Private & Avrasya & 237,91688 & 5 & 26 \\
\hline 17 & Black Sea & 1982 & State & Karadeniz Teknik & 236,46107 & 326 & 57 \\
\hline 18 & Eastern Anatolia & 2006 & State & Van Yüzüncü Yıl (Ercişs) & 229,68239 & 3 & 29 \\
\hline 19 & Eastern Anatolia & 1984 & State & İnönü & 227,04871 & 149 & 14 \\
\hline 20 & Eastern Anatolia & 2010 & State & Erzurum Teknik & 227,04406 & 2 & 37 \\
\hline 21 & Southeastern Anatolia & 2007 & State & Kilis 7 Aralık & 214,01646 & 10 & 36 \\
\hline
\end{tabular}

*Source: The data were obtained from the websites of the universities.

**Source: Center for Evaluation, Selection, and Placement, 2017.

When Internet sites are analyzed by the Content Analysis method, the words of Internet sites are compared (Erdem and Gezen, 2014: 24). Visual or functional features were not used for comparison. According to the Content Analysis method, information on the websites of the universities was compared with the induction method and 194 criteria shown in Appendix 1. The Content Analysis scores obtained according to the information contained in the Internet pages of the department of business administration of the universities are shown in Table 1. When contents are analyzed, induction and word counting methods are taken as the type of research. The distribution of Content Analysis scores received by the universities is also shown in Figure 1. 


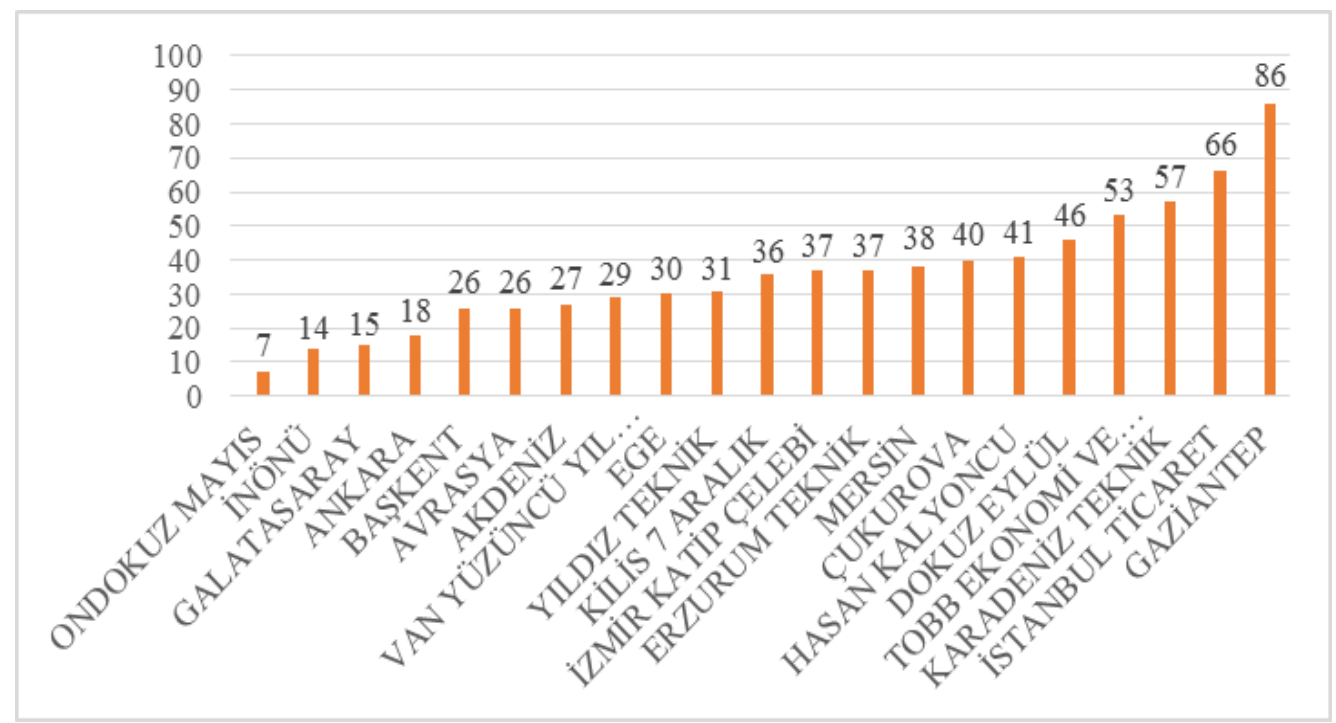

Figure 1. Distribution of Content Analysis Scores of Universities

When Content Analysis scores are examined, it can be seen that universities can be classified in the lower and upper quartiles of the number of universities. For this reason, the activity levels in the 21 observations were low for the first 5 observations, high for the last 5 observations, and middle for the other observations. However, looking at the sequential values, the 5th and 6th units have the same Content Analysis score, so the 5th observation is considered to be in the medium activity level. However, when the sequential values are examined, the 5th and 6th units have the same Content Analysis score, so the 5th observation is considered as the middle level.

Activity levels related to the use of Internet pages by universities: Dokuz Eylül, TOBB Ekonomi ve Teknoloji, Karadeniz Teknik, İstanbul Ticaret and Gaziantep universities are active at the high level; Ondokuz Mayıs, İnönü, Galatasaray and Ankara universities are active at the low level and the other universities are active at the middle level.

The content scores obtained as a result of the Content Analysis, the base points and the number of preferred Candidates shown in Table 1 constitute variables of the Cluster Analysis. The IBM SPSS Statistics 21 computer program was used for the Cluster Analysis method.

In the Cluster Analysis, the average link cluster method and the method of measuring the square root mean square distance between groups were selected. The quantitative values of the variables are normalized between $0-1$ for normalization. The dendrogram graph obtained as a result of the Cluster Analysis is given in Figure 2.

It can be seen from the results of the Dendrogram graph that the cluster is evaluated as 3 clusters. In the case of clusters having 3 clusters, it is seen that Dokuz Eylül University is different from other universities in terms of the number of preferred candidates. Galatasaray and TOBB Ekonomi ve Teknoloji Universities are differentiated due to the base point variable. It was observed that the effect of content scores on the Cluster Analysis was less than the base score and the number of preferred candidates. In the case of 4 clusters in the Cluster Analysis, the content scores of Gaziantep and Istanbul Ticaret Universities differ from other universities and are in a different cluster. 


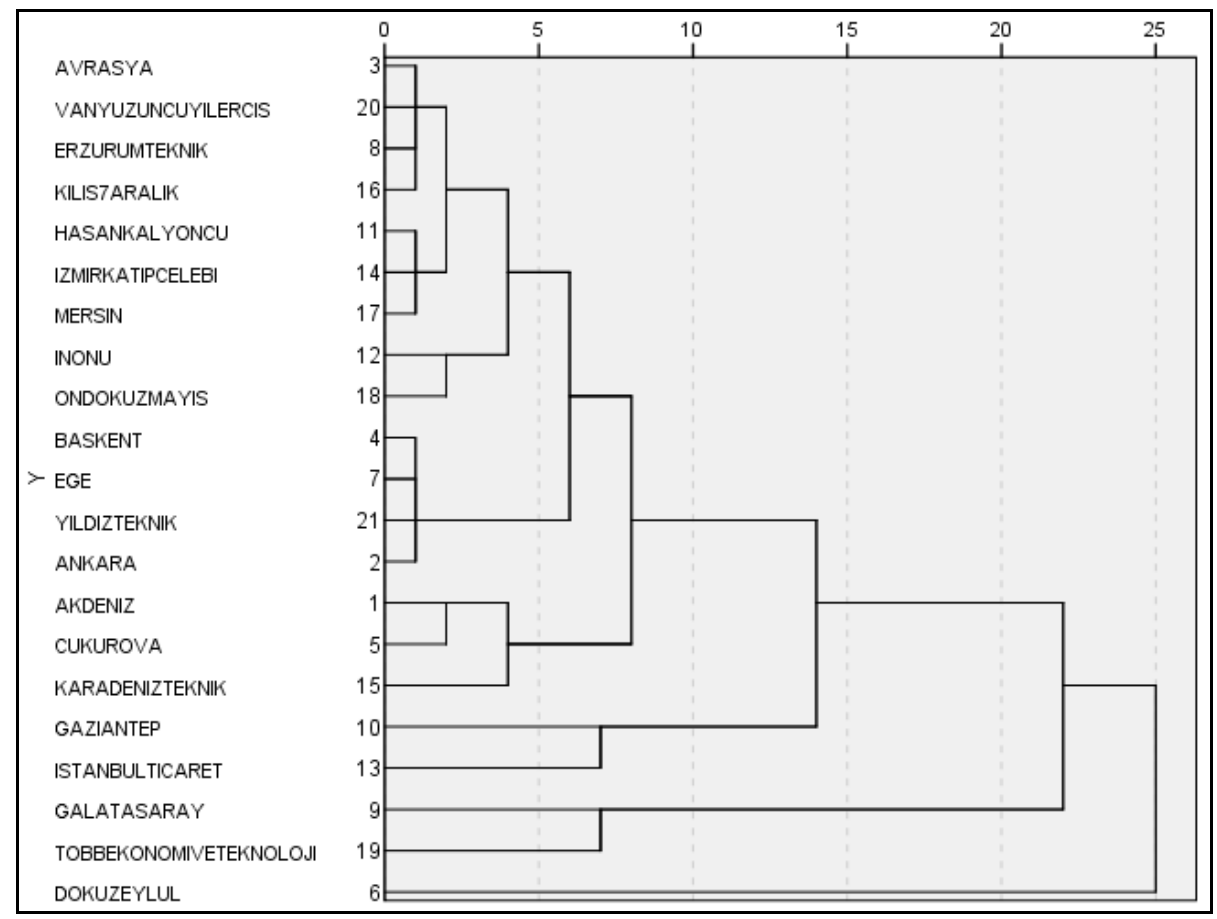

Figure 2. Cluster Analysis of Universities

\section{RESULTS}

The Internet has become one of the indispensable elements of life today. Individuals benefit from using the Internet for many different purposes. Adapting to rapid changes in the age of information technology should be one of the primary goals of universities where the Internet is heavily used. During university education, students often use the Internet pages of their departments for information or communication about current topics, processes, activities, and conferences etc. In order to respond to the changing needs and expectations of the students, the departments should make sure that the internet pages are deficient and updated.

The Internet pages of the department of business administration of the universities in the sample group were evaluated for descriptive analysis by Content Analysis method. It is recommended that the ineffective Ondokuz Mayıs, İnönü, Galatasaray and Ankara universities renew the content of their internet pages of department of business administration as content. In addition, the Council of Higher Education may designate at least the properties that the sites must carry in order to use the Internet pages of the universities effectively. In this way, informing university students and candidate students about the department can be made effective. Universities may be able to overcome the shortcomings of Internet pages based on the content of universities that are effectively evaluated.

Cluster Analysis comparison criteria were the content scores of the web pages of the business administration of universities, the base scores announced by Center for Evaluation, Selection, and Placement in 2017 and the number of students who are eligible to study in the department of business administration. As a result of the Cluster Analysis, it was determined 
that the university structure, the region where the university is located, or the foundation year is not an effective criterion in the cluster of universities.

In this study, Content Analysis method of qualitative research types is integrated with Cluster Analysis method which is a quantitative research type. Such an application was not encountered in the Content Analysis studies from the literature search. This aspect of the study contributes to the literature. It may also be advisable to increase the sample size or to use different variables for further studies.

\section{REFERENCES}

Akdeniz University. (2017). Department of Business Administration, Access Date: 28 October 2017, URL: http://isletmebolumu.akdeniz.edu.tr/.

Aktay, A. \& Ekşi, H. (2009). The Relationship between Organizational Citizenship Behaviours and Value Preferences of Teachers and Principals. Turkish Journal of Business Ethics, 2(3), 19-65.

Anderberg, M. R. (1973). Cluster Analysis for Applications. London: Academic Press, Inc.

Ankara University. (2017). Department of Business Administration, Access Date: 28 October 2017,

URL:http://www.politics.ankara.edu.tr/?bil=bil_icerik\&icerik_id=261\&menu=0\&ens_b irim $=2200$.

Antalyal1, Ö. Ü. (2008). Domains of Organizational Effectiveness in Turkish Universities: A Research on Faculty Members. Antalya: Süleyman Demirel University, Institute of Social Sciences, Department of Business Administration, Doctoral Thesis.

Antonenko, P. D., Toy, S., \& Niederhauser, D. S. (2012). Using Cluster Analysis for Data Mining in Educational Technology Research. Educational Technology Research and Development, 60(3), 383-398.

Aşan, Z. (2015). The Examination of Social Economic Variables of Credit Card Owner Costumers with Cluster Analysis. Dumlupinar University Journal of Social Sciences, (17), Access Date: 28 October 2017, URL: http://dergipark.gov.tr/dpusbe/issue/4759/65384.

Avrasya University. (2017). Department of Business Administration, Access Date: 28 October 2017, URL: http://isletme.avrasya.edu.tr/.

Ay, Ü., \& Koca, A. İ. (2012). The Content Analysis of ISO 500 Firms' Vision, Mission and Values. Journal of Organization and Management Sciences, 4(2), 201-210.

Başkent University. (2017). Business Administration, Access Date: 28 October 2017, URL: http://isl.baskent.edu.tr/kw/index.php.

Bayram, M., \& Yaylı, A. (2009). Evaluation of Hotel Web Sites Using Content Analysis. Electronic Journal of Social Sciences, 8(27), 347-379. 
Becan, C. (2011). The Evaluation of Corporate Social Responsibility in Terms of Stakeholder Theory and Communication Approach: A Content Analysis towards Press Releases of Banks. Journal of Selcuk Communication, 7(1), 16-35.

Center for Evaluation, Selection and Placement (2017). 2017 ÖSYS Yerleştirme Sonuçlarına İlişkin Sayısal Bilgiler. Access Date: 25 September 2017, URL: http://www.osym.gov.tr/TR,13312/2017-osys-yerlestirme-sonuclarina-iliskin-sayisalbilgiler.html.

Çakmak, Z. (1999). Kümeleme Analizinde Geçerlilik Problemi ve Kümeleme Sonuçlarının Değerlendirmesi. T. R. Kutahya Dumlupınar University Journal of Social Sciences, 3(3), 187-205.

Çiçek, H., Demirel, M. \& Onat, O. K. (2010). A Research on the Assesment of Enterprises Websites: Burdur Province Case. Suleyman Demirel University the Journal of Faculty of Economics and Administrative Sciences, 15(2), 187-206.

Çiltaş, A., Güler, G., \& Sözbilir, M. (2012). Türkiye' de Matematik Eğitimi Araştırmaları: Bir İçerik Analizi Çalışması. Educational Sciences: Theory \& Practice, 12(1), 565-580.

Çukurova University. (2017). Department of Business Administration, Access Date: 28 October 2017, URL: http://business.cu.edu.tr/tr/.

Demirtaş, M. C., \& Özgüven, N. (2012). Evaluation of Mayors Web Sites in Terms Of Political Marketing Applications. Academic Review of Economics and Administrative Sciences, 5(2), 238-252.

Doğan, N., \& Başokçu, T. O. (2010). İstatistik Tutum Ölçeği için Uygulanan Faktör Analizi ve Aşamalı Kümeleme Analizi Sonuçlarının Karşılaştırılması. Journal of Measurement and Evaluation in Education and Psychology, 1(2), 65-71.

Dokuz Eylül University. (2017). Business Administration, Access Date: 28 October 2017, URL: http://iibf.deu.edu.tr/akademik-birimler/isletme/.

Duran, B. S., \& Odell, P. L. (1974). Cluster Analysis, a Survey. Berlin: Springer-Verlag.

Durrant, P. (2017). Lexical Bundles and Disciplinary Variation in University Students' Writing: Mapping the Territories, Applied Linguistics, 38(2), 165-193.

Ege University. (2017). Department of Business Administration, Access Date: 28 October 2017, URL: http://iibf.ege.edu.tr/tr/isletme-bolumu/.

Erdem, A. R. (2005). Üniversitenin Var Oluş Nedeni (Üniversitenin Misyonu). Pamukkale University Journal of Education, 17(17), 75-86.

Erdem, B., \& Gezen, T. (2014). The Examination of Job Advertisements for Tourism Establishments by Content Analysis Method. International Journal of Management Economics and Business, 10(21), 19-42.

Erdogmuş, N., \& Esen, M. (2016). Classifying Universities in Turkey by Hierarchical Cluster Analysis. Education and Science, 41(184), 363-382.

Erzurum Teknik University. (2017). Department of Business Administration, Access Date: 28 October 2017, URL: http://iibf.erzurum.edu.tr/Menu?id=156. 
Everitt, B. S., Landau, S., Leese, M., \& Stahl, D. (2011). Cluster Analysis, 5th Edition. United Kingdom: John Wiley \& Sons, Ltd.

Galatasaray University. (2017). Department of Business Administration, Access Date: 25 September 2017, URL: http://isletme.gsu.edu.tr/.

Galloway, K. R., \& Bretz, S. L. (2015). Using Cluster Analysis to Characterize Meaningful Learning in a First-Year University Chemistry Laboratory Course. Chemistry Education Research and Practice, 16(4), 879-892.

Gaziantep University. (2017). Department of Business Administration, Access Date: 128 October 2017, URL: https://www.gantep.edu.tr/ab/index.php?bolum_id=402.

Güreş, N., Arslan, S., \& Yalçın, R. (2013). A Research on the Assesment of Airline Companies Web Sites. Academic Review of Economics and Administrative Sciences, 6(1), 173-185.

Hasan Kalyoncu University. (2017). Department of Business Administration, Access Date: 28 October 2017, URL: http://isl.hku.edu.tr/.

Hennig, C., Meila, M., Murtagh, F., \& Rocci, R. (2016). Handbook of Cluster Analysis. Boca Raton, FL: Taylor \& Francis Group CRC Press.

Ho, H.-F., \& Hung, C.-C. (2008). Marketing Mix Formulation for Higher Education: an Integrated Analysis Employing Analytic Hierarchy Process, cluster analysis and correspondence analysis. International Journal of Educational Management, 22(4), 328340.

Hosseini, S. M. S., Maleki, A., \& Gholamian, M. R. (2010). Cluster Analysis Using Data Mining Approach to Develop CRM Methodology to Assess the Customer Loyalty. Expert Systems with Applications, 37(7), 5259-5264.

Hsieh, H. F., \& Shannon, S. E. (2005). Three Approaches to Qualitative Content Analysis. Qualitative Health Research, 15(9), 1277-1288.

İnönü University. (2017). Department of Business Administration, Access Date: 28 October 2017, URL: https://cms.inonu.edu.tr/tr/cms/isletme.

İstanbul Ticaret University. (2017). Department of Business Administration, Access Date: 28 October 2017, URL:http://www.ticaret.edu.tr/tr/Sayfa/Akademik/Fakulteler/TicariBilimler/Bolumler /isletme.

İzmir Katip Çelebi University. (2017). Department of Business Administration, Access Date: 28 October 2017, URL: http://isl.ikc.edu.tr/.

Kalimullin, A. M., \& Dobrotvorskaya, S. G. (2016). Higher Education Marketing Strategies Based on Factors Impacting the Enrollees' Choice of a University and an Academic Program. International Journal of Environmental \& Science Education, 11(13), 6025-6040.

Karadeniz Teknik University. (2017). Department of Business Administration, Access Date: 28 October 2017, URL: http://www.ktu.edu.tr/isletme.

Kassarjian, H. H. (1977). Content Analysis in Consumer Research. Journal of Consumer Research, 4(1), 8-18. 
Kerr, D., \& Chung, G. K. (2012). Identifying Key Features of Student Performance in Educational Video Games and Simulations through Cluster Analysis. Journal of Educational Data Mining, 4(1), 144-182.

Kilis 7 Aralık University. (2017). Department of Business Administration, Access Date: 28 October 2017, URL: http://iibf.kilis.edu.tr/bolum/IIII02/bolum/isletme-bolumu.

Kurulgan, M., \& Bayram, F. (2006). Content and Form Anaysis of the Web Sites of University Libraries: A Study on the Case in Turkey. Turkish Librarianship, 20(2), 141-172.

Leech, N. L., \& Onwuegbuzie, A. J. (2007). An Array of Qualitative Data Analysis Tools: a Call for Data Analysis Triangulation. School Psychology Quarterly, 22(4), 557-584.

Lu, W. Z., He, H. D., \& Dong, L. Y. (2011). Performance Assessment of Air Quality Monitoring Networks Using Principal Component Analysis and Cluster Analysis. Building and Environment, 46(3), 577-583.

Mayring, P. (2000). Qualitative Content Analysis. Forum Qualitative Sozialforschung/Forum: Qualitative Social Research, 1(2), Art. 20 - June, Access Date: 20 November 2017, URL: http://nbn-resolving.de/urn:nbn:de:0114-fqs0002204.

Mersin University. (2017). Business Administration, Access Date: 28 October 2017, URL: http://www.mersin.edu.tr/akademik/iktisadi-ve-idari-bilimlerfakultesi/bolumler/isletme-bolumu/programlar/isletme.

Ondokuz Mayıs University. (2017). Business Administration, Access Date: 28 October 2017, URL: http://iibf.omu.edu.tr/lisans/isletme.

Öz, B., Taban, S., \& Kar, M. (2009). A Comparison of Turkey with the EU in terms of Human Capital Indicators through Cluster Analysis. Eskişehir Osmangazi University Journal of Social Sciences, 10(1), 1-29.

Özdemir, M. (2010). Qualitative Data Analysis: a Study on Methodology Problem in Social Sciences. Eskişehir Osmangazi Üniversitesi Sosyal Bilimler Dergisi, 11(1), 323-343.

Postareff, L., Mattsson, M., Lindblom-Ylänne, S., \& Hailikari, T. (2017). The Complex Relationship between Emotions, Approaches to Learning, Study Success and Study Progress During the Transition to University. Higher Education, 73(3), 441-457.

Primack, B. A., Kim, K. H., Shensa, A., Sidani, J. E., Barnett, T. E., \& Switzer, G. E. (2012). Tobacco, Marijuana, and Alcohol Use in University Students: a Cluster Analysis. Journal of American College Health, 60(5), 374-386.

Sandelowski, M. (2000). Focus on Research Methods-Whatever Happened to Qualitative Description?. Research in Nursing and Health, 23(4), 334-340.

Stemler, S. (2001). An Overview of Content Analysis. Practical Assessment, Research $\mathcal{E}$ Evaluation, 7(17), Retrieved December 2, 2014, Access Date: 03 November 2017, URL:http://PAREonline.net/getvn.asp?v=7\&n=17.

Şahin, M., \& Gülnar, B. (2016). The Relationship between Communication Apprehension and Internet Usage: a Survey among Turkish University Students. Journal of Selçuk Communication, 9(2), 5-26. 
TOBB Ekonomi ve Teknoloji University. (2017). Business Administration, Access Date: 28 October 2017, URL: https://www.etu.edu.tr/tr/bolum/isletme.

Tosunoğlu, B., \& Çam, A. V. (2016). A Research on the Postgraduate Thesis in the Field of Cost in Turkey. Gümüşhane University Electronic Journal of the Institute of Social Sciences, 7(15), 145-155.

Turkish Statistical Institute. (2017). Information Society Statistics. Access Date: 14 September 2017, URL: http://www.tuik.gov.tr/PreTablo.do?alt_id=1028.

Üsdiken, B., Topaler, B., \& Koçak, Ö. (2013). Law, Market and Organizational Diversity: Turkish Universities in the Post-1981 Period. The Journal of the Faculty of Political Science, 68(03), 191-227.

Van Yüzüncü Yıl University. (2017). Department of Business Administration, Access Date: 28 October 2017, URL: https://ercisisletme.yyu.edu.tr/AkademikBirimler/index.php?s=177.

Vecchio, R., \& Annunziata, A. (2013). Consumers' Attitudes towards Sustainable Food: a Cluster Analysis of Italian University Students. New Medit, 12(2), 47-56.

Weare, C., \& Lin, W. Y. (2000). Content Analysis of the World Wide Web: Opportunities and Challenges. Social Science Computer Review, 18(3), 272-292.

Yildız Teknik University. (2017). Department of Business Administration, Access Date: 28 October 2017, URL: http://www.isl.yildiz.edu.tr/.

Y1ld1z, S. (2014). What do universities promise? A Content Analysis of Print Ads of the Universities in Turkey. Anadolu University Journal of Social Sciences, 14(2), 155-170. 
Appendix 1. Content Analysis Comparison Criteria

\begin{tabular}{|c|c|c|}
\hline Language & About (Publicity) & Projects and Achievements \\
\hline Search & Workflow Processes & Virtual Tour \\
\hline Sitemap & Brochure \& Handbook & $\begin{array}{l}\text { Publication Research Projects } \\
\text { Coordination Board }\end{array}$ \\
\hline Home Page & Video & Academic Opportunities \\
\hline Administration & Photo (Gallery) & Quality Assurance, Quality Unit \\
\hline Boards & Logo History & Board Agendas \\
\hline $\begin{array}{l}\text { Department of Health, Culture and } \\
\text { Sports }\end{array}$ & $\begin{array}{l}\text { Prime Ministry Center for } \\
\text { Communications (BİMER) }\end{array}$ & Application and Research Centers \\
\hline Activity Reports & Lateral/Vertical Transfer & Campus Life \\
\hline Faculties and Institutes & Double Major & $\begin{array}{l}\text { Campus Safety (Harassment } \\
\text { Prevention) }\end{array}$ \\
\hline Academic Staff & International Office & $\begin{array}{l}\text { Psychological Counseling and } \\
\text { Guidance }\end{array}$ \\
\hline Administrative Staff & International Student & Student Awards \\
\hline Academic Meetings & International Student Exam & 360 Degrees Campus Publicity \\
\hline Administrative Meetings & Exchange Programs Coordinator & $\begin{array}{l}\text { University Information } \\
\text { Management System }\end{array}$ \\
\hline Guest Academics & Erasmus & Technical Services \\
\hline Syllabus & Mevlana & Support (Help) \\
\hline Postgraduate Syllabus & Farabi & University Association \\
\hline Exam Program & Arabic Program & Technopark \\
\hline Base Points and Quotas & $\begin{array}{l}\text { Bologna Course Information and } \\
\text { Qualifications }\end{array}$ & $\begin{array}{l}\text { Knowledge Commercialization } \\
\text { Center }\end{array}$ \\
\hline $\begin{array}{l}\text { Career Opportunities \& Career } \\
\text { Planning Coordinator }\end{array}$ & $\begin{array}{l}\text { Thought and Project Production } \\
\text { Academy }\end{array}$ & Life Long Learning Coordinator \\
\hline Internship \& Cooperative Education & Academic Calendar & Virtual Shop \\
\hline Graduate Information Form & Candidate Student & Live Support \\
\hline News & Quick Access & Information Package \\
\hline Announcements & Other Units & Primary Schools \\
\hline Activities & $\begin{array}{l}\text { Administrative and Financial } \\
\text { Affairs Unit }\end{array}$ & Health Organizations \\
\hline Portal & Personnel Affairs Unit & Library \\
\hline Dormitories & Information Unit & Application Hotels \\
\hline Transportation & Information Application Form & Art and Culture \\
\hline Contact & Data Processing Unit & Social Responsibility \\
\hline Address & Student Affairs & Sports Facilities \\
\hline Phone & Departments & Sport Teams \\
\hline Phone Book & Other Departments & Commissions \\
\hline Fax & Lesson Plans & Assistant Representative \\
\hline E-mail & Lesson Contents & Student Representative \\
\hline Map & Distance Learning System & Student Clubs \\
\hline Twitter & Prep School & External Relations Coordinator \\
\hline Flickr & Undergraduate & Study In Turkey \\
\hline Linkedin & Associate Degree & Invest In City \\
\hline Facebook & $\begin{array}{l}\text { Undergraduate Course } \\
\text { Curriculum }\end{array}$ & Gaziantep City (Promotion) \\
\hline $\begin{array}{l}\text { Student (Consultancy, Regulations, } \\
\text { Exam Program, Syllabus) }\end{array}$ & $\begin{array}{l}\text { Internet Assisted Language } \\
\text { Learning Institutions }\end{array}$ & $\begin{array}{l}\text { European Studies Application } \\
\text { and Research Center }\end{array}$ \\
\hline Youtube & Postgraduate Education & Academic Archive \\
\hline Google+ & Postgraduate Programs & Development Plan \\
\hline
\end{tabular}




\begin{tabular}{|c|c|c|}
\hline \multicolumn{3}{|l|}{ Appendix 1. (cont.) } \\
\hline Links & Master's Degree & Ministry of Youth and Sports \\
\hline Wishes and Complaints & Doctorate & Course Matching Principles \\
\hline Mission and Vision & Job Descriptions & $\begin{array}{l}\text { Electronic Document } \\
\text { Management System }\end{array}$ \\
\hline Objectives & $\begin{array}{l}\text { Legislation, Regulations and } \\
\text { Directions }\end{array}$ & $\begin{array}{l}\text { Electronic Document } \\
\text { Management System Informing }\end{array}$ \\
\hline Basic Values & $\begin{array}{l}\text { Thesis/Capstone Project Writing } \\
\text { Guide }\end{array}$ & $\begin{array}{l}\text { Higher Education Information } \\
\text { System (YÖKSİS) }\end{array}$ \\
\hline Instagram & Forms and Petitions & $\begin{array}{l}\text { Diploma Supplement (Equivalent } \\
\text { Certificate) }\end{array}$ \\
\hline Student Counseling & Research Topics & Provincial Publicity \\
\hline Student Handbook & $\begin{array}{l}\text { Agreed Foundation and } \\
\text { Companies }\end{array}$ & Hospital \\
\hline Turkish Education & Three Term Student & Strategic Planning \\
\hline $\begin{array}{l}\text { Distance Education (History } \\
\text { Lesson) }\end{array}$ & Student Information System & $\begin{array}{l}\text { Provincial Examination } \\
\text { Coordinator }\end{array}$ \\
\hline $\begin{array}{l}\text { Education Facilities (Lecture } \\
\text { Theater, Classroom, Library etc.) }\end{array}$ & Department Information System & Internal Evaluation Report \\
\hline Social Facilities & Course Management System & Invention Notice \\
\hline Guest House & E-mail Server (Eduroam) & Television \\
\hline Disabled Student Unit & $\begin{array}{l}\text { Academic Performance } \\
\text { Indicators }\end{array}$ & Data Processing Unit User Guide \\
\hline Public File Server & $\begin{array}{l}\text { Academic Project Process } \\
\text { Management System }\end{array}$ & $\begin{array}{l}\text { Animal Experiments Research } \\
\text { and Ethics Committee }\end{array}$ \\
\hline Newspaper & $\begin{array}{l}\text { Scientific Research Projects } \\
\text { Management }\end{array}$ & Ethical Committees \\
\hline Radio & Laboratories & E-Registration \\
\hline Continuing Education Center & $\begin{array}{l}\text { Faculty Member Training } \\
\text { Program (ÖYP) }\end{array}$ & QR Code \\
\hline Student E-mail & Retired Academic Staff & Internal Control \\
\hline Technology Transfer Office & Publications & Education and Youth Programs \\
\hline Personnel E-mail & Journals & Ministry of National Education \\
\hline $\begin{array}{l}\text { Social Policy Application and } \\
\text { Research Foundation }\end{array}$ & $\begin{array}{l}\text { Publications Published in } \\
\text { International Journals in the Last } \\
\text { Two Years }\end{array}$ & Council of Higher Education \\
\hline Personnel Information System & $\begin{array}{l}\text { Coordination of Common } \\
\text { Courses }\end{array}$ & $\begin{array}{l}\text { Scientific and Technological } \\
\text { Research Council of Turkey }\end{array}$ \\
\hline $\begin{array}{l}\text { Center for Evaluation, Selection, } \\
\text { and Placement (ÖSYM) }\end{array}$ & $\begin{array}{l}\text { Higher Education Student Loans } \\
\text { and Dormitories Institution } \\
(\mathrm{KYK})\end{array}$ & \\
\hline
\end{tabular}

